\title{
Soil erosion and policy initiatives in India
}

\author{
Debashis Mandal and Nishita Giri*
}

Though soil erosion is a natural phenomenon, the rate of erosion has been increased 10 to 100 times because of land conversion (e.g. land conversion from forest to agriculture) and land management (overgrazing, expansion of cultivation). However, behind this land transformation some, socio-cultural and policy decision acts as drivers. Ancient humans had a good knowledge to prevent soil erosion through terracing even 4000 years ago. The decline of civilizations has been closely linked with the degradation of their resources particularly deforestation, accelerated soil erosion and the decline of crop yields. Historical evidences are crucial and provide alternative proxies about soil erosion in the past. Among the various factors, it is portrayed that natural situations, cultural traditions and socio-economic, and governance played a major role in the dynamics and rates of soil erosion in a long-term perspective. Ensuring harmony and keeping balance with nature is a great challenge in a democratic polity with a fast-expanding market economy.

Keywords: Conservation initiatives, land degradation, soil erosion.

LAND degradation especially soil erosion is considered as a major environmental problem in India ${ }^{1}$ affecting about 83 million ha ( $\mathrm{m} \mathrm{ha}$ ) area ${ }^{2}$. The connection linking topsoil removal and land degradation is initiated from a nondegraded stable state; however, several drivers and pressures accelerate it. Historically, such drivers were deforestation, shifting cultivation, over-cutting of vegetation, over-ploughing of land along with population pressure and climate change. Since prehistoric times, humans also realized that worsening land degradation caused by anthropogenic activities is undermining the well-being of humanity. In recent times, a novel approach has been taken to achieve land degradation neutrality by 2030 . India has set a target of achieving $26 \mathrm{~m}$ ha neutrality by 2030.

It is generally said that history repeats itself. Same is the case with the rise and fall of many civilizations, including the Indus Valley Civilization. We should learn lessons from the historical records for developing strategies and plans to reverse the trend of land degradation. During the Neolithic period, nearly 8000-4000 BCE, agropastoral and shifting cultivation were the normal livelihood options. However, land use was in harmony with the environment and resource utilization was extremely cordial in the society ${ }^{3}$. It is true that due to clearance of forest for fodder and fuelwood, some ecological imbalances were created and the problem of soil erosion accelerated. However, till the advent of agriculture, humanity

Debashis Mandal and Nishita Giri are in the ICAR-Indian Institute of Soil and Water Conservation, Dehradun 248 195, India.

*For correspondence. (e-mail: nishi28nov@gmail.com) was getting all the benefits from nature. Importance of forest conservation has been highlighted in the Upnishads and Arayankas, and Kautilya's Arthshastra.

In the early Holocene soil erosion was weak due to very low precipitation and dry environment. Throughout the mid-Holocene, soil erosion was less than the soil formation rate, since luxurious vegetation cover protected the soil even though rainfall was high. An increase in soil erosion started when hunting and pastoral life began to change gradually to a sedentary lifestyle, and at present, soil erosion is about four times greater than the geological erosion rate ${ }^{4}$. However, the first major peak erosion occurred at the end of Bronze age (or $1000 \mathrm{BCE}$ ), when post-Vedic people introduced the iron plough and started cultivation by burning down forest lands ${ }^{5}$.

Ancient humans had a good knowledge to prevent soil erosion through terracing even 4000 years ago, much before scientific research. From times immemorial, bunds and tals were made and the importance of contour bunding and gully plugging were understood ${ }^{6}$.

Caste system and social governance system largely helped in maintaining a state of equilibrium through economic actions and ecological niche ${ }^{3}$.

Colonial administration and policies dramatically altered the traditional form of land texture. Policies that enable investment in better livelihoods generation are the best for promoting investment in better land husbandry. Policies will not be effective unless the economic conditions of rural people are improved, who are still living just at or below the survival level even today. The primary difficulty is whether the governance and managerial power should be decentralized first, or whether the resources should be redistributed first. 


\section{Soil erosion and conservation in ancient India}

Soil erosion is not new; perhaps the phenomenon is as old as the formation of the earth itself ${ }^{7}$. Although a fraction of the erosion is accredited to unavoidable natural causes, there is large substantiation that erosion is caused by anthropogenic activities in the form of mounting infringement of forests, deforestation, overgrazing of grasslands and extension of agricultural land ${ }^{8}$. Since the dawn of the civilization, soil and water resources have been the fundamental ingredients of our life-support system on earth. Great civilizations flourished where these natural capitals were available in ample quantities, and they perished with the depletion of the latter. Historically therefore, civilizations began to respect these natural elements and found the most excellent way of utilizing them. Respect to the soil is best illustrated in the concept of 'Pancha bhootas'; these are soil, air, fire, water and space that comprise the most primary state of the divine process $^{7}$.

In the vedic literature like Atharvaveda, many hymns mention about the importance of soil and water resources of the earth. If we cause harm to Mother Earth, it may lead to imbalance on the earth's systems. Likewise, Yajurveda also explains 'if we disturb earth and space surrounding they will also disturb us" ${ }^{\text {" }}$. In the Rigveda, Tittiriya Samhita, Khadira Grihya Sutra, Yajurveda and Maitrayani Samhita we can find references to agricultural practices with emphasis on conservation of soil resources ${ }^{10,11}$. History reveals that the Aryans, who came to India about $1500 \mathrm{BCE}$, were mainly pastoral and agricultural people, and major forest areas remained untouched during that time ${ }^{6}$.

Ancient Aryans emphasized on correct agricultural practices and were conscious of the need of preservation and conservation of land, water, plants and animals. They recognized the use of resources for their well-being as well as for their cattle. They not only worshipped trees like Ficus religiosa, Ficus benghalensis, Mangifera indica, Aegel marmelos, etc. but also animals and birds like cows, peacocks, etc. Sometimes patches of a particular vegetation are worshipped by the forest communities; these are called as 'sacred grooves'. They play an important role in the preservation of vegetative cover under mounting biotic pressure ${ }^{12}$.

According to historical records, three most important anthropogenic erosion peaks can be recognized in India. The first occurred at the peak period of river valley civilizations around 3000 years ago, because of excessive deforestation and removal of pasture to make land for cultivation. Heavy disturbance of forest habitats may have been caused by various environmental factors, including climate deterioration, human impact and forest fire. Human impact on forest clearance has been reported through pollen study in a Garhwal Himalayan lake between 2000 and $480 \mathrm{BC}$, when the post-Harappa migrants reached the foothills of Himalaya and Yamuna Ganges Doab. In Kumaon Himalaya, iron smelting sites at Uleni (Almora district) dated 1022-826 BC and Tehri Garhwal were discovered. The presence of plant fragments indicated increased fire activity and deforestation between $480 \mathrm{BC}$ and $\mathrm{AD} 1050$. Moderate grazing activities were also noted in the same period ${ }^{13}$

Large tracks of North India and Peninsular India were brought under intensive cultivation during $500 \mathrm{BC}$ and $\mathrm{AD}$ 300. The large surplus of agricultural products could have promoted trade within the territory and overseas, the Mauryas and Kushanas in the north and Chalukyas and Sangam in the peninsula ${ }^{3}$. Surely, this land transformation significantly contributed to soil erosion.

Religious beliefs in Buddhism and Jainism also played a role in promoting trade with an appeal to people to protect land, vegetation and animals as in many region soils were so depleted that food production was under threat.

Since Alexander's invasion (326 BC), gradual disappearance of forests in the Indian subcontinent is indicated in some areas. Expansion of agriculture into forested land and marginal grasslands was the dominant factor determining erosion ${ }^{8}$. During the Mughal period, cropping intensity further increased with a mixture of subsistence agriculture and commercial crops.

Realizing the importance of soil and water conservation, many lakes were constructed under the patronage of the Maurya emperors. Historical evidence reveals that in AD 150 climatic disaster violence destroyed the embankments of the lakes ${ }^{14}$. Hsuen Tsang recorded extensive forest in the Gangetic valley. The banks of River Yamuna were also wooded during the reigns of Mahmud of Gazni in the 11 th century AD. Nine hundred years later, Ain-EAkbari, mentioned royal forests near Punjab, Haryana and western Uttar Pradesh regions of India ${ }^{15}$. In the 13 th century, the dense track of forested land between Delhi and Badaun was removed by the order of Emperor Allaudin to make passage for traders and travellers. Soil history with humans is both cultural and intellectual. What people believe about soils influences what they do with them; either they conserve and nurture soils, or abuse and abandon them. What people understand and misunderstand about soils is thus a necessary part of any history of the nexus between soil and society ${ }^{16}$.

The second peak, during the period 1800 and 1900, occurred due to migration from Europe. Through the enterprise of an exportation type of cultivation, the immigrants encouraged the local peasants to expand agriculture and disturb the more erodible, fragile lands, while keeping the improved lands for commercial purpose. The third peak from the early 20th century and extending to the modern days occurred mainly with an increasing population demanding for more land and food production. This population pressure forced farmers to develop suitable 
lands for agriculture production and adopt intensive, non-conserving land-use and land-management techniques which cause dramatic soil erosion. In many places, the risk of erosion has been documented and suitable control measures adopted. In some regions, erosion constantly causes widespread sedimentation and water quality problems. Resource degradation and society interact in such a way that soil erosion affects human lives and livelihood, and human actions regularly enhance soil $\operatorname{erosion}^{17}$.

\section{Soil erosion and conservation during the colonial period}

During the British era, the lower Indo Gangetic Plains had a marshy environment covered with thick jungles which impeded the early growth of agriculture. Gradually, agricultural settlements in cleared forest lands increased for various reasons. Although man has been deforming the natural order from the earliest and primitive times, the scales of intervention and resulting effects have been increased many folds during colonial expansion. During 1880-1950, about $20 \mathrm{~m}$ ha of forest area was converted to agricultural land. The main focus of the colonial administration was to increase revenue from timber export as well as infrastructure development ${ }^{3}$.

Road construction, transportation and mining activities in hill areas have resulted in serious landslides. The semiarid regions, the foothills of the Aravalis and Shivaliks are subjected to severe sheet and gully erosion. The ravines of Yamuna and Chambal are continuously moving into the fertile Gangetic Plains. People are still trying to cultivate much of these areas and thus contributing to further destruction ${ }^{6}$. In fact, under 'grow more campaigns' during the World Wars (1920-1950), even hilly areas as the Nilgiris in the south were brought under the plough, which accelerated erosion hazards in the country.

In 1852, forest land settlement under the British rule was made in south-central region of Rajasthan and land was distributed to petty landlords who wasted no time to sell their property. Thus forests were quickly destroyed within a period of 30 years, there was complete deforestation in the entire Ajmer-Mewar region. All this happened because of uncontrolled use of forest land and subsequently erosion had accelerated due to lack of vegetation. Figure 1 shows the area (ha) under cho (torrents) beds at four successive settlements (years) in Hoshiarpur district, Punjab, India ${ }^{18}$.

Controversial treaties were signed between local elites (zamindars) and colonial administrative lands, including forests were reclassified. Local peasants and tribes in many places were removed and resettled, which consequently led to the lack of farming and grazing lands, decreased human and livestock mobility, and disappearance of traditional knowledge and practices for dealing with risks and fostered conflict over resources. In many places the habitual use of land was influenced by conventional systems of resource utilization and preservation that involved a mix of religious customs, myths and traditions in regulating both the magnitude and form of exploitation. For example, the Baigas in the central and eastern parts of India resisted commercial cultivation using iron plough due to their beliefs. In some places the evicted jhum cultivators were forced to infringe into forests situated in fragile areas and to adopt mechanisms of shortening the following period (recovery period in an ecologically sustainable manner) and intensifying crop production, which in turn increased soil erosion. The local communities have a moral authority that is incontestable. This is vital if conservation is to be rooted at the local level ${ }^{12}$.

Dyadic claims and counter claims during the colonial period evolved a complex system leading to politically, socially and economically differentiated groups. Substantial proportion of area under slash and burn cultivation in the Western Ghats, Eastern Ghats and the hilly Northeast region were expropriated for commercial crop cultivation and plantation of tea, coffee and rubber.

Shifting cultivators were forced to adopt strategies of shortening the follow period and intensifying crop production ${ }^{19}$. Once this practice was ecologically most suitable, it becomes unfriendly to environment in its distorted form.

For example, potato cultivation increased from 75.3 ha during 1847 to about 8097.2 ha during $1949-50$ in the Nilgiris, which demanded many other developmental activities to promote the same ${ }^{20}$. The colonial administration made a vicious downward spiral, whereby the poor were forced to overuse environmental resources for survival $^{21}$.

With increasing pressure of land degradation, India has been continuously using sustainable soil management techniques through a range of approaches. In 1994, India joined the United Nations Convention to Combat Desertification (UNCCD) and recently committed to achieving land degradation neutrality of at least $26 \mathrm{~m}$ ha by 2030 .

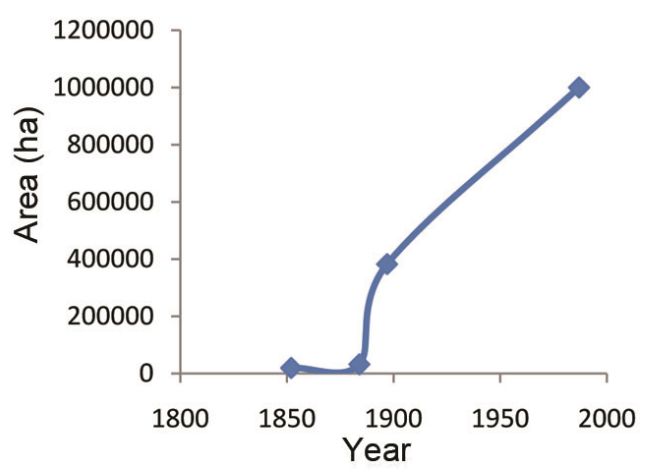

Figure 1. Change in area under torrents in Hoshiarpur, Punjab, India during successive years. 
Table 1. A concise compilation of several soil conservation initiatives and projects

\begin{tabular}{|c|c|c|}
\hline Year & Programme/policy and relevant institution & Objectives and achievements \\
\hline \multicolumn{3}{|c|}{ Pre-independence period } \\
\hline 1900 & First soil and water conservation (SWC) by Punjab state & Recognition of soil erosion problem \\
\hline 1920 & Ravine reclamation project & $\begin{array}{l}\text { Reclamation project for ravines took place in the United } \\
\text { Province (Uttar Pradesh) }\end{array}$ \\
\hline 1928 & Royal Commission on Agriculture & $\begin{array}{l}\text { Highlighted moisture conservation and suitability of crops for } \\
\text { dryland region }\end{array}$ \\
\hline 1930 & $\begin{array}{l}\text { Dryland farming research scheme and setting up of the Indian } \\
\text { Council of Agriculture Rsearch (ICAR) }\end{array}$ & $\begin{array}{l}\text { To develop SWC techniques for better farming in semiarid lands at } \\
\text { Manjri, Pune, Maharashtra }\end{array}$ \\
\hline 1938 & Dry farming scheme & Stress on contour bunding \\
\hline 1945 & Enactment of Famine Commission & SWC was adopted as a part of relief measures. \\
\hline
\end{tabular}

Post-independence period

1947-48 Damodar Valley Corporation Act was passed

1953 The Central Soil Conservation Board started functioning.

1954-56 Setting up of the Central Soil and Water Conservation Research and Training Institute (CSWCRTI), Dehradun

1961 Launching of river valley schemes

1962 An initiative of soil conservation in the catchments of river valley projects (RVPs) was started in India

1973-74 Drought Prone Areas Programme (DPAP) by the Ministry of Rural Development (MoRD), Government of India (GoI)

1977-78 Desert Development Programme (DDP) by MoRD, GoI

1980-81 Integrated watershed management and rivers having potential to cause floods launched in the sixth Five Year Plan

1981-82 Lab-to-land programme and launching of model watershed development projects for development of drylands

198347 operational research projects

1988 National Forest Policy (NFP).

Integrated watershed management approach was undertaken in the catchment area to provide irrigation, power generation and to moderate floods.

To initiate research in SWC

Run-off and soil loss studies have been conducted since 1955

Agriculture has undergone drastic changes through the application of various newly developed techniques in agrosciences

The scheme thrived to control premature siltation of reservoirs, which in turn enhances productivity of the catchment areas

To tackle the areas constantly affected by severe drought conditions

To minimize adverse effects of drought and desertification through reforestation

To enhance productivity of degraded lands and minimize siltation of reservoirs

The scientists found good response to the programme from the farmers who adopted improved agricultural practices

For soil and water conservation in drylands

This helped adopt different criteria of minimum forest area in different states

1989-90 Integrated Wasteland Development Project (IWDP) by MoRD, To promote employment generation in rural areas by development GoI

1990-91 National Watershed Development Project for Rainfed Areas (NWDPRA)

1992 National Conservation Plan

1994 Guidelines for watershed development (WSD) by MoRD, GoI of wastelands and regeneration of non-forest land.

To promote sustainable natural resource management and restore ecological balance

To tackle the problem of sustainable land-use management system in agroforestry programmes

To provide common guidelines for WSD focused on participatory role.

The 1994 WSD guidelines were updated to have a more flexibility in implementation

This helped integrated community institutions more meaningfully in DPP, DPAP and IWDP, and simplify the procedures

To enhance rural livelihood by providing employment through manual work (e.g. SWC, afforestation and land development)

To establish common guidelines for all WSD schemes for the development of rainfed farming scheme

Provides framework to guide WSD projects in all departments and ministries

Consolidated three programmes, viz. IWDP, DPAP and DPP

Amendments to the 2008 guidelines

New features added to the 2008 common guidelines to ensure momentum to the IWMP

IWMP was brought under this programme to extend irrigation and to improve water-use efficiency with the motto 'Har Khet Ko Paani'.

Source: Refs 9, 22 and 23. DPP, Drought Preparedness Partnership. 
India has planned various policies and programmes to address soil erosion and land degradation problems (Table 1).

Colonial administration and policies dramatically altered the traditional form of land texture. The colonial administration worked with priorities of generating imprudent revenue for a self standing colonial rule. In pre-colonial India, resources use was as per the biocapacity of nature and resource sharing among the multiple segments of the society was extremely cordial ${ }^{3,24}$.

During the First World War, a large number of trees and bamboo were exported to the Middle East for use of the British military. The Second World War was more devastating for Indian forests. With emphasis on massive industrialization in independent India during the initial Five-Year Plan periods, forests were indiscriminately exploited to supply raw materials to the industries, eventually making them commercially viable. The 73rd and 74th Amendment Acts (1992) of the Constitution brought land-use conservation, management and related issues under the purview of local bodies in both rural and urban areas.

\section{Conclusion}

Historical evidences are crucial and an invaluable source to provide alternative proxies about soil erosion in the past. During the early prehistoric periods, soil erosion was primarily considered as a regional phenomenon; however, it had extended to much larger areas. Among the various factors, natural situations, cultural traditions, socio-economic conditions and governance play an important role in causing and controlling soil degradation in the long term. Ancient humans had good knowledge to prevent soil erosion through terracing, even about 4000 years ago. The downfall of many civilizations across the globe has been closely connected with resource degradation, primarily cutting of trees, accelerated loss of topsoil and reduction in crop productivity. Landscape destruction with reduction in biocapacity of local resources ultimately affects socio-ecological resilience. Policies that enable investment in better livelihoods generation are the best strategy for promoting investment in better land husbandry. Policies will not be successful unless the economies of millions of peasants are improved.

In independent India, attention has been paid for controlling soil erosion in different agro-climatic regions of the country. Peasants often appreciate soil conservation measures proposed by various agencies. However, they failed to adopt such measures to effectively control soil erosion because of their fragmented land holdings and poor economic conditions. Elite people are more deeply politicized than ever before with intensified competition for living space, water, and fertile as well as marginal lands. Economic transformations through energy genera- tion, building large dams, over-mining and over-pumping of water largely are the main drivers now causing land degradation. Therefore, ensuring harmony and maintaining a balance with nature is a great challenge in a democratic polity with a fast-expanding market economy. Many renowned historians, ecologists and social scientists have also expressed a similar view ${ }^{12}$.

1. Mandal, D. and Sharada, V. N., Assessment of permissible soil loss in India employing a quantitative bio-physical model. Curr. Sci., 2011, 100(3), 383-390.

2. Mandal, D., Giri, N. and Srivastava, P., The magnitude of erosioninduced carbon $(\mathrm{C})$ flux and $\mathrm{C}$-sequestration potential of eroded lands in India. Eur. J. Soil Sci., 2020, 71, 151-168.

3. Gadgil, M. and Guha, R., This Fissured Land: An Ecological History of India, Oxford India Perennials, Oxford University Press, New Delhi, 1992, ISBN-13:978-0-19-807744-2.

4. Xiubin, H., Tang, K. and Zhang, X., Soil erosion dynamics on the Chinese Loess Plateau in the last 10,000 years. Mt. Res. Dev., 2004, 24(4), 342-347.

5. Abrol, Y. P., Sangwan, S. and Tiwari, M. K., Land UseHistorical Perspectives: Focus on Indo-Gangetic Plains, Allied Publishers, New Delhi, 2002, ISBN: 81-7764-274-X.

6. Dhruvanarayana, V. V., Soil and water conservation research in India. Indian Council of Agriculture Research, New Delhi, 1993.

7. Brown, L. R., Outgrowing the Earth: The Food Security Challenge in an Age of Falling Water Tables and Rising Temperatures, Earth Policy Institute, Landon, UK, 2005, p. 235, ISBN: 1-84407185-5.

8. Blaikie, P., The Political Economy of Soil Erosion in Developing Countries, Longman, London, UK, 1985, p. 188.

9. Tejwani, K. G., Soil and water conservation research in India (a historical and Futuristic perspective). Indian. J. Soil Conserv., 1994, 22(1-2), 1-14.

10. Saxena, D. P., Regional Geography of Vedic India, In Grantham, Kanpur, 1976.

11. Nene, Y. L. and Sadhale, N., Agriculture and biology in Rigveda. Asian Agri-Hist., 1997, 1(3), 177-190.

12. Rangarajan, M., Nature and Nation: Essay on Environmental History, Ashoka University History Series, 2015, ISBN: 978-817824-500-3.

13. Demske, D. Tarasov, P. E., Leipe, C., Kolia, B. S., Joshi, L. M. and Long, T., Record of vegetation, climate change, human impact and retting of hemp in Garhwal Himalaya (India) during the past 4600 years. Holocene, 2016, 1-15; doi:10.1177/095968336166 50267.

14. Babu, M. S. U. and Nautiyal, S., Historical Issues and Perspectives of Land Resource Management in India: A Review, Working Paper 309, The Institute for Social and Economic Change, 2013. ISBN 978-81-7791-165-7.

15. Pant, G. B. and Kumar, K. R., Climates of South Asia. In The Soil Peace Nexus: Our Common Future, Soil Science and Plant Nutrition (ed. Lal, R.), John Wiley, Chichester, UK, 1997, vol. 61(4), pp. 566-578; doi:10.1080/00380768.2015.1065166.

16. McNeill, J. R. and Winiwarter, V., Soil, soil's knowledge and environmental history: an introduction. In Soils and Societies: Perspectives from Environmental History (eds McNeill, J. R., John, R., and Winiwarte, V.), The White House Press, Cambridge, UK, 2010, pp. 1-6.

17. Cogo, N. P. and Levien, R., Erosion and productivity, human life. In Encyclopedia of Soil Science (ed. Lal, R.), CRC Press, Boca Raton, 2002, pp. 428-431; ISBN: 0-8243-0518-1.

18. FAO, Soil Conservation and Management in Developing Countries, FAO Soils Bulletin No. 33, Food and Agriculture 
Organization of the United Nations. Rome, Italy, 1985, p. 208; ISBN 92-5-100430-7.

19. Thapa, G. B. and Weber, K. E., Soil erosion in developing countries: a politico economic explanation. Environ. Manage., 1991, 15(4), 461-473.

20. Tripathi, K. P. and Samraj, P., Problem of soil erosion and conservation strategies in the southern hill region with particular reference to the Nilgiris. Indian J. Soil Conserv., 1994, 22(1-2), 94-101.

21. Blaikie, P. and Brookfield, H., Land Degradation and Society, Methuen, London, 1987; http://doi.org/10.1177/03091325880120 0425 .

22. TERI, Economics of desertification land degradation and drought in India. Mesoeconomic assessment of the cost of land degrada- tion in India. The Energy and Resource Institute, New Delhi, 2018, vol. 1, p. 168.

23. Reddy, B. V. C., Hoag, D. and Shobha, B. S., Economic incentives for soil conservation in India. In ISCO 2004 - 13th International Soil Conservation Organisation Conference, Brisbane, Australia, July 2004.

24. Blakie, P. M. and Mauldavin, J. S. S., Upstream, China, India: the politics of environment in the Himalayan region. Ann. Assoc. Am. Geogr., 2004, 94(3), 520-548.

Received 21 January 2020; revised accepted 23 November 2020

doi: $10.18520 / \mathrm{cs} / \mathrm{v} 120 / \mathrm{i} 6 / 1007-1012$

\section{Corrigendum}

\section{Climate change, cryosphere and impacts in the Indian Himalayan Region}

A. P. Dimri, S. Allen, C. Huggel, S. Mal, J. A. Ballesteros-Cánovas, M. Rohrer, A. Shukla, P. Tiwari, P. Maharana, T. Bolch, R. J. Thayyen, M. Stoffel and Aayushi Pandey

[Curr. Sci., 2021, 120(5), 774-790]

A. P. Dimri was mistakenly affiliated with School of Geography and Sustainable Development, University for St Andrews, Scotland, UK. His affiliation should have been School of Environmental Sciences, Jawaharlal Nehru University, New Delhi 110 067, India and T. Bolch was wrongly affiliated with Department of Geography, University of St Andrews, UK. His affiliation should have been School of Geography and Sustainable Development, University of St Andrews, Scotland, UK. The errors have been corrected in the PDF version of the article. 